\title{
Gender Equality or Social Equity; Lessons from Traditional Non- Gendered Egalitarianism
}

\author{
Dr Orina Felix Ayioka*, Makarios Wakoko \\ Department of English, Literature \& JMC, Kibabii University
}

*Corresponding Author: Dr Orina Felix Ayioka, Department of English, Literature \& JMC, Kibabii University

\begin{abstract}
Twentieth century gender activism has accomplished wide-ranging social transformation. Today, there is little obstruction to anyone pronouncing themselves on matters affecting women, from access to education to representation. Nonetheless, the yearning to have societies where power truly belongs to all is still a persisting reality. The argument that the boy child is now not getting the attention is due to him is ever gaining more currency. There is, therefore, need to strive for a truly egalitarian society; a society founded on justice and equity. The present paper, while guided by the following two essential questions, focuses on how exemplar traditional social structures-known for their communal egalitarian relations, collective authority and economies-could enrich modern efforts towards social justice: a) What is the contrast between traditional and modern experiences and knowledge on gender? b) To what extent can the unique existential African gender experiences and conditions be admissible to modern gender perceptions? The main objective of the study is not only to elucidate the origin and causes of gender injustices, but also highlight practices and traditions that help entrench the so-called gender inequalities. The main thesis of the study holds that gender inequality is both a traditional and modern (postcolonial) problem; hence approaches that are purely modern may not be able to completely alleviate perceived imbalances. In analyzing relevant issues, the study uses the various strands of feminism theory. Ultimately, the study proposes a paradigm shift that emphasises historical causes of gender bigotry in addition to identifying useful lessons from traditional egalitarianism for fighting hegemonic systems, a shift that may turn out to be useful in contemporary gender studies.
\end{abstract}

\section{INTRODUCTION}

Consensus lacks on the best possible means of ending hegemonic designs that engrain mass disenfranchisement and inequity within and between communities. This paper looks at gender as a social and cultural phenomenon which may be most resourcefully expended if considered in its total context. The aim is to show that wholly modern/traditional approaches may not alleviate perceived imbalances since gender inequality is neither purely traditional nor modern (postcolonial). Hence, exemplar traditional social structures - given their communal egalitarian relations, collective authority and economies - could help realize just modern societies.

Wanjiku Mukabi Kabira (1992) avers that traditional creators of knowledge are ignored because they are not members of the elite (57). In a rejoinder, Lesiba Teffo (2011), in Rural Communities as Sites of Knowledge: A Case for African Epistemologies, calls for sustained "liberation of traditional knowledge systems and the incorporation of unique existential experiences in the general corpus of science knowledge and ways of knowing" (1).

Ngugi wa Thiong'o, on his part, blames ineffective aspects of modern gender activism on the tendency to generalize and marginalize:

This misleading stock interpretation of the African realities has been popularized by the western media which likes to deflect people from seeing that imperialism is still the root cause of many problems in Africa. Unfortunately some African intellectuals have fallen victims-a few incurably so - to that scheme and they are unable to see the divide-and-rule colonial origins of explaining any differences of intellectual outlook or any political clashes in terms of the ethnic origins of the actors... The conflicts between peoples cannot be explained in terms of that which is fixed. Otherwise the problems between any two peoples would always be the same at all times and places. (1-2) 
Ngugi is, clearly, calling for diversified approaches. Raewyn Connel (2000) supports by decrying the contradictory and arbitrary nature of the gender theory: "the gender position that society constructs for men may not correspond exactly with what men are, or desire to be, or what they actually do. There exists a determined but misguided assumption that, gender issues are merely about women's welfare." (2) Consequently, gender studies as an area that could benefit from such integrated experiences. The concept of "gender" is next examined.

\section{GENDER: A CASE OF IDEOLOGICAL INCONGRUITY}

The most espoused definition of gender terms it "those differences between men and women that are socially constructed. These differences include such stereotypical beliefs as: men are strong - women, weak; men are politicians - women, artists; men assist each other - women, fight each other; men are outgoing - women, inward looking" (Kabira 1992, 59-60). Margaret Simmonds (2012) posits that although the distinction between sex and gender had been alluded to by Simone de Beauvoir in 1949, 'gender' as a concept was popularized in the 1970s by Robert Stoller who was the first to point out a distinction between four important gender-related concepts: sex, gender, gender identity and gender role (Stoller 1964, 1968). The term 'gender role' was subsequently rejected by feminists. (Simmonds 2012, 12).

Mari Mikkola (2017), counts Patrick Geddes and John Arthur Thompson among the most notorious sexists. Geddes and Thompson (1889), in The Evolution of Sex, argue that social, psychological and behavioural traits were caused by metabolic state. Women are said to be anabolic - conserve energymaking them passive, conservative, sluggish, stable and uninterested in politics while men are katabolic - expend surplus energy making them eager, energetic, passionate, variable and, therefore, interested in political and social matters. Mikkola avows that the main feminist motivation for making the distinction between 'sex' and 'gender' was to counter biological determinism or the view that biology/one's sex was destiny. Feminists could then argue that many differences between women and men were socially produced and therefore changeable, culminating in the social learning theory.

Catherine Mackinnon (1980) opposes the social learning theory using her theory of sexuality which says that the social meaning of sex (gender) is created by sexual objectification of women whereby women are viewed and treated as objects for satisfying men's desires. Consequently, masculinity is defined as sexual dominance and femininity as sexual submission. As a result, genders are by definition hierarchical and this hierarchy is fundamentally tied to sexualised power relations. The notion of 'gender equality', then, does not make sense to Mackinnon, because if sexuality ceased to be a manifestation of dominance, hierarchical genders (those defined in terms of sexuality) would cease to exist (Mankinnon 1980 in Mikkola 2017).

Elisabeth Spelman (1988), with her theory of 'particularity of race, class, ethnicity and nationality' also opposes gender realism theory arguing that if gender were separable from all other factors, then all women would experience womanhood in the same way. Stone (2007) is, for instance, quoted as having observed that the history of racist oppression illustrates that during slavery black women were 'hypersexualised' and thought to be always sexually available whereas white women were thought to be pure and sexually virtuous. For Spelman, therefore, the perspective of 'white solipsism' - which assumes that all women share some 'golden nugget of womanness'-underlies gender realists' mistake (Spelman 1988, 159 in Mikkola 2017).

Similarly, Judith Butler's deconstructs sex/gender distinction through two claims of her normativity argument (1990): first, Feminist Identity Politics — gender unitary notions which fail to recognise 'the multiplicity of cultural, social, and political intersections in which the concrete array of 'women' are constructed' (Butler 1999, 19-20). According to Butler, therefore, identity categories are never merely descriptive, but always normative, and as such, exclusionary (Butler, 1991, 9). Second, Butler fronted 'Gender Performativity'. Gender is performative because it is instituted through a stylised repetition of acts; a doing rather than a being. Gender only comes into being through "gendering acts... and ultimately the aim should be to abolish norms that compel people to act in these gendering ways" (Buttler 199, 179). Butler then suggests two ways of engaging in feminism appropriately: one, that feminists should not try to define women at all and, two, the category of women 'ought not to be the foundation of feminist politics'. Rather feminists should focus on providing an account of how power functions and shapes our understandings of womanhood not only in the society at large but also within the feminist movement (Buttler 199, 9 quoted in Mikkola 2017). 
Butler's views echo those of Gayle Rubin's description of gender as 'socially imposed division of the sexes'. This implied that feminism should aim to create a 'genderless (though not sexless) society, in which one's sexual anatomy is irrelevant to who one is, what one does, and with whom one makes love (Rubin 1975, 204 quoted in Mikkola 2017). Though clearly well reasoned out, Rubin's 'genderless' society seems not welcome among certain feminists as Marjorie Oudhe Macgoye, Bessie Head, Sibi-Okumu, etc. who have resisted the 'feminist label' in order to, among other reasons, 'avoid restrictive categorization' (Kurtz 2005, 68). Sibi-Okumu is on record:

You see, I think what I have to say is that I like being a woman. I haven't the faintest doubt that I have the advantage of men, who will never be able to bring a child to birth. And you would expect that when people take the label 'feminist' that they would be rejoicing in that womanliness,... but I think that some of us are so determined to become like men that we have thrown out the baby with the bathwater (Kurtz 2005, 68).

Macgoye, on her part, argues that sexual differences are divinely established and any attempt to eradicate them will be ill-advised. In Moral Issues in Kenya, she urges readers to retain a sense of those things that would be considered unique to the female experience: "the joy and responsibility of motherhood, the gift of nourishing and healing, the artistic insight' (Macgoye 1996, 74 quoted in Kurtz 2005, 68). Further, according to Kurtz, Macgoye is no doubt affected by the fact that mainstream feminism, as it has been translated into Africa from its European and American roots, too frequently reflects the concerns and biases of those alien origins, not always being attentive to the specific issues of African women. "FOR African women, siding with feminism sometimes can mean siding with colonial or western ideology" (Kurtz 2005, 69). The apparent lack of consensus on matters gender confirms the need for more diverse and inclusive approaches. Below, the historical and cultural approach of gender studies is delineated.

\section{The Historical/Cultural Theory and Method}

Marianne Gullestand (1993), in her condemnation of generalised equality-seeking mentalities, argues that the assumption that women everywhere are subordinated to men is no longer a useful guideline in gender investigations: 'the axiom of universal subordination assumes what should be examined and reduces the ability of the analyst to uncover the subtleties, contradictions and ambiguities of gender relations in different contexts (Gullestand 1993, 128 in Egara kabaji 2000, 5). Kabaji explains that a genuine and thorough examination has to take into consideration the African socio-cultural context and the values that govern the sexes.

Similarly, Maria Lugones (2007) has decried the overly assuming and single minded focus on patriarchy. She declares: "I have seen over and over, often in disbelief, how politically minded white theorists have simplified gender in terms of the patriarchy. The intersection between race, class, gender and sexuality should be investigated in a way that enables me to understand the indifference that men... who have been racialized as inferior exhibit to the systematic violence inflicted upon women of colour" (188). Lugones believes that the concerns Third-world feminists fight using Western methods are not even Western because they were specifically designed for the third-world:

Colonialism did not impose pre-colonial, European gender arrangements on the colonised. Rather, it imposed a new gender system that created very different arrangements for colonised males and females than for white bourgeois colonisers. Thus, it introduced many genders and gender itself is colonial concept and mode of organization of relations of production, property relations, of cosmologies and ways of knowing (Lugones 2007, 185).

According to Lugones, for one to understand this system of gender, there is need to historicise gender. She says:

The reason to historicize gender formation is that without this history we keep on centering our analysis on patriarchy; that is, on a binary, hierarchical, oppressive gender formation that rests on male supremacy without any clear understanding of the mechanisms by which heterosexuality, capitalism and racial classification are impossible to understand apart from each other. The heterosexualist patriarchy has been an a historical framework of analysis. To understand the relation of the birth of the colonial/modern gender system to the birth of colonial global capitalism ... is to understand our present organization of life anew it is also essential to understanding the extent and importance of the gender system in disintegrating communal 
relations, egalitarian relations, ritual thinking, collective decision making and authority and economies. (187)

Clearly, lack of understanding leads to wrong approaches in dealing with concerns that relate to women in the Third-world feminists:

In the development of twentieth-century feminism, the connections among class, gender, and heterosexuality as racialized were not made explicit. That feminism centred its struggle and ways of knowing and theorizing against a characterization of women as fragile, weak in both body and mind, secluded in the private and sexually passive. But it did not bring to consciousness that those characteristics only constructed white bourgeois womanhood. Indeed beginning from that characterization, white bourgeois feminists theorized white womanhood as if all women were white (Lugones 2007, 202).

It may then be observed that most gender-equality movements in Africa are not only founded on rather contradictory premises but could immensely benefit from contextualized methods.

\section{Pre-Colonial Egalitarian Systems: Discussion and Illustrations}

Steve Biko (1978) says about traditional African way of life: "One of the most fundamental aspects of our culture is the importance we attach to man. Ours has always been a man-centred society." (41) He adds: "The African personality with its attitude of laying less stress on power and more stress on man is well on the way to solving our confrontation problems" (44). Equally, Oyeronke Oyewumi (1997), in The Invention of Women, raises questions about the validity of patriarchy as a valid trans-cultural category. Her argument is that "gender was not an organising principle in Yoruba society prior to colonisation by the West" (Oyewumi 1997, 20 in Lugones 2007, 31). No gender system was in place. She says:

(Gender) became important in Yoruba studies not as an artefact of Yoruba life but because Yoruba life, past and present, has been translated into English to fit the Western pattern of body reasoning. (30)

Oyewumi then terms Western 'gender' as a tool of domination that designates two binary opposed and hierarchical social categories. 'Women' (the gender term) is not defined through biology but in relation to men, the norm: 'Women are those who do not have a penis; those who do not have power; those who cannot participate in the public arena' (Oyewumi 1997, 34 in Lugones 2007, 196). The pre-colonial era was different:

One tradition that was exported to Africa during this period was the exclusion of women from the newly created colonial public sphere... resulted, in part, from the imposition of the colonial patriarchal state....The transformation of state power to male-gender power was accomplished at one level by the exclusion of women from state structures. This was in sharp contrast to Yoruba state organisation, in which power was not gender-determined (Oyewumi, 1997, 12325 in Lugones 2007, 197).

A state where power is not gender-determined but is available for all in society to appropriate is what Maria Lugones refers to as 'non-gendered egalitarianism'. She says:

While in the West the challenge of feminism is to proceed from the gender-saturated category of 'women' to the fullness of an unsexed humanity. For Yoruba obinin, the challenge is obviously different because at certain levels in the society and in some spheres the notion of an 'unsexed humanity' is neither a dream to aspire to nor a memory to be realised. It exists, albeit in concatenation with the reality of separate and hierarchical sexes imposed during the colonial period (156 in Lugones 2007, 196).

Lugones seeks to make it clear that the status of white bourgeois women is "much inferior to that of Native American or Yoruba women before colonisation" (203). Lugones further cites Paula Gunn Allen who presents most Native American tribes as gynecratic: "Many American Indian tribes thought that the primary potency in the world was female, and that understanding authorizes all tribal activities' (Allen 1986/1992, 26 in Lugones 2007, 198). Old Spider Woman, Corn Woman, Serpent Woman, Thought Woman are some of the names of powerful creators. For the gynecratic tribes, Woman is at the centre and 'nothing is sacred without her blessing, her thinking' (Allen 1986/1992, 13 in Lugones 2007, 198). According to Allen, the "inferiorization" of the Indian females is thoroughly tied to the domination and transformation of tribal life. She says: 
Among the features of the Indian society targeted for destruction was the two-sided complimentary social structure...system of reciprocity...: internal female chief and an external male chief. The internal chief presided over the band, village or tribe...The red, male, chief presided over mediations between the tribe and outsiders (Allen 1986/1992, 18 in Lugones 2007, 199-200).

Gender was not understood on primarily biological terms. Most individuals fit into tribal gender roles "on the basis of proclivity, inclination and temperament. The Yuma's had a tradition of gender designation based on dreams; a female who dreamed of weapons became a male for all practical purposes" (Allen 1986/1992, 196 in Lugones 2007, 200). It is this 'inferiorization' and attempts to erase the traditional history that Lugones calls 'the dark side of the gender system'.

Similarly, Nelson Nyang'era (1986), in The Making of Man and Woman under Abagusii Customary Laws says women's roles were not exactly menial. In fact, only women were trusted to intercede for families or entire tribe. King'oina says:

Early morning when the sun had arisen, the mother took her baby outside and did point her breasts to the sun, squeezed milk out while uttering the words - rioba nderere nainche nkorere (sun, nurse this baby for me as I nurse it for you too (15)

Whenever there was a persistent drought, women of impeccable character performed Ribina dance at the top of Manga Hills which is still considered a sacred ground.

Egara Kabaji (2000) explains that "individuals will always challenge fixed identities and unfair power relations in ongoing and sometimes subtle ways" (2). He further observes:

One of the most interesting aspects about the Maragoli form of settling disputes...is the idea of 'sleeping on the word before delivering a verdict. In most cases, it is the elders who listen to cases and deliverer judgment. However, women are only called in to give evidence. After listening to a case, the men adjourn the session in order to 'sleep on the word' before a verdict is offered.... Closer examination of this concept reveals that the men give themselves time to consult with their wives. (48)

Yet in most traditional systems manhood was earned. In Margaret Ogola's The River and the Source, the narrator says: 'Otieno treated his wives like sluts and they did not fail him. Owuor treated his wife like queen and she did not fail him either (Ogola, 17). In the same text, only women of distinguished character are celebrated. Akoko, the main character/feminist voice, says:

Has anyone ever seen me gossiping with other women at the water hole? Do I always not rise early to till my lands? Have I ever begged for food from you my mother-in-law as all your daughters-in-law do? Do I not always have enough to eat and more left over to batter in exchange for cattle, goats and sheep? Indeed the rise of her herd had become quite impressive (Ogola, 35).

There is also evidence in many Gusii oral texts that women of good deeds were honoured. In the chant Omokungu Omong'aini (A Wise Woman), diligent women are praised as the centre holding the tribe together. A home with a foolish woman was doomed. Likewise, in another song, Ng'ina Banto Omuya (Good Mother of People), mothers are presented as the source of happiness.

Conversely, women of contemptible character were lampooned. In a song titled $\mathrm{Ng}$ 'ererie obokombe (Give me a hoe), neighbours are warned about listless lingering women whose beauty is comparable that captured in proverbs 11:22 which is like gold ring in a Pig's snout. The beautiful woman is lazy; a master of deceit. Nonetheless, some portrayals of women were not allowed to stand without contest. In a song, Mogaka otachi meino (A grown man who can't sing), women also spelt out standards up to which their men needed to measure: authoritative and charismatic, otherwise they were much derided. Some songs by women bordered on outright provocation. Echae ya'morero Toe (Give us hot tea) is full of defiance and cheekiness. A traditional initiation song, women covertly demand for fulfilling relationships (coitus) with their spouses. It may then be observed that, in a number of traditional orders, power was contested for by all - man or woman - perhaps, to the exception of those who were debilitated in one way or the other and were, therefore, a responsibility to society as a whole. Power 
was a privilege enjoyed by all who had mastered the art of wielding, whether, as revealed above, through show of charisma, wit and/or artistry.

\section{CONCLUSION AND RECOMMENDATIONS}

It may have been clear from the foregoing discussion that some traditional communities were not only highly democratic but also quite just. Egalitarian communities were organised on the basis of equity and democracy which ensured that all members were treated fairly and impartially and enabled equally to meet their potential. The Yoruba, for instance, assigned their women important roles based on individual inclinations and temperament. Native American tribes such as the Hurons, the Iroquois, the Yuma and the Cherokee are not only said to have been predominantly matriarchal but also practiced a two-sided complimentary social system that did not understand gender on primarily biological terms.

Equally, gender distinction is not only both a colonial but also a form of patriarchal domination. Lugones says: "This gender system congealed as Europe advanced the colonial project(s). It took shape during the Spanish and Portuguese colonial adventures and became full blown in late modernity" (Lugones 2007, 185). It is in the background of such historical realities that methods that seek 'gender equality' without first understanding the history of social inequalities become more and more flawed, particularly in their dictatorial and contradictory tendencies. With such an understanding, it then means that factors that breed inequality, such as lack of access to education, security and sexual harassment, water, food and universal suffrage may not only be identified but should, indeed, be addressed individually and strictly according to the law. Such methods should be more effective than those that that Risman (2003) terms lacking in social transformation credentials and which 'may slip without intention into the implicitly value-free role of social scientists who study gender merely to satisfy intellectual curiosity, (quoted in Risman 2004, 445). The best feminist methods would then be those that recognise that societies do not treat their women (and men) in a homogenous manner. Christine Mungai, while quoting anthropologist David Gilmore, has argued that cultures that have got limited resources, and have to fight over territory, battling the elements of nature have 'seriously hardcore' concepts of masculinity and, therefore no coincidence, that some of the most severe masculine (and sometimes, feminine) rites of passage in Africa are in harsh or arid environments. In contrast, cultures in lush places, such as Philippines and Tahiti where the social concept of 'being a man' was much relaxed had higher levels of equity (Mungai, March 25 2017, 45). It may therefore be necessary to not only pay attention to cultural differences but also device methods that do not make calls for gender equality a permanent political endeavour as opposed to facilitating a situation where social equity is attained through a permanent removal of gender. Modern mechanisms, such as the celebrated Bill of Rights in chapter four of the Kenyan constitution, which the real aspirations of the Kenyan people are stated, can realise the desired social equity.

\section{REFERENCES}

[1] Beauvoir, S. (1949). The second sex. New York: Vintage

[2] Biko, S. (1978). I Write What I Like. London: Heinemann.

[3] Butler, J. (1990). Gender Trouble . London: Routledge .

[4] Foucault M. (1980). Power/ Knowledge, U.K: Harvester.

[5] Kabaji, E. (2005). The Construction of Gender Through the Narrative Process of the African Folktale: A Case Study of the Maragoli Folktale. Pretoria: University of South Africa.

[6] Kabira, W. (1992). The Oral Artist and the Gender Dimension. In O. O. (Eds), Refrections on Theory and methods in Oral Literature (pp. 12-28). Nairobi: Views Media.

[7] Kurtz, R. (2005). Nyarloka's Gift the Writing of Marjorie Oludhe Macgoye. Nairobi: MvuleAfrica.

[8] Lugones, M. ((Winter, 2007), Vol. 22, No. 1). Heterosexualism and the Colonial / Modern Gender System. Hypatia, Writing Against Heterosexism , p. 186-209.

[9] Mikkola, M. (Winter 2017). Feminist Perspectives on Sex and gender. In E. Z. (Ed), The Stanford Encyclopedia of Philosophy. Stanford: Metaphysics Research Lab, Stanford University.

[10] Nyang'era, N. ( 1986). The Making of Man and Woman under Abagusii Customary Laws . Nairobi: Acacia Publishers.

[11] Ogola, M. (1995). The River And The Source. Nairobi: Focus Publishers. 
[12] Spivak, G. (1985). Theory and Practice in Feminist Scholarship (Ed.). Paula, A, Treichler,

[13] Cheris, Kramarae and Beth. Stafford: University of Illinois.

[14] Teffo, L. (2013, Vol 12, Issue 2). rural communities as sites of knowledge: a case of african epistemologies. indiliga african journal of indigenous knowledge systems, 188-202.

[15] Thiong'o, g. w. (1986). Decolonising the Mind. London: Heinemann.

\section{AUTHOR'S BIOGRAPHY}
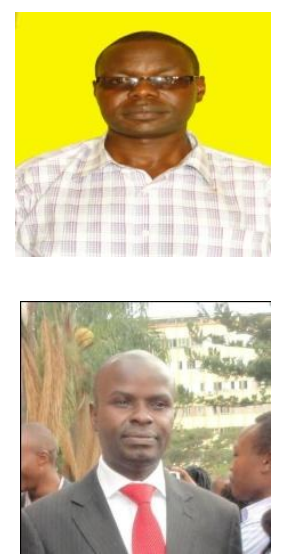

Felix Orina is a lecturer in the Department of English, Literature, Journalism and Mass Communication at Kibabii University, Western Kenya, with research interests in African literature - both continental and of the Diasporas-Indigenous African oral literature, and the popular culture. He has published several papers in various scholarly refereed journals.

Makarios Wakoko is a Tutorial Fellow in the Department of English, Literature, Journalism and Mass Communication at Kibabii University. His research interests include Literature, Language and Culture of the peoples of East Africa. He is widely published in language and sociolinguistics.

Citation: Dr Orina Felix Ayioka, Makarios Wakoko. "Gender Equality or Social Equity; Lessons from Traditional Non-Gendered Egalitarianism". International Journal of Humanities Social Sciences and Education (IJHSSE), vol 5, no. 9, 2018, pp. 85-91. doi: http://dx.doi.org/10.20431/2349-0381.0509012.

Copyright: (C) 2018 Authors. This is an open-access article distributed under the terms of the Creative Commons Attribution License, which permits unrestricted use, distribution, and reproduction in any medium, provided the original author and source are credited. 